\author{
Li Moli Francesco, ${ }^{1}$ Sh.N. Abdikul, ${ }^{2}$ (D) S.K. Ahmetkalieva ${ }^{3}$ iD \\ ${ }^{1}$ Universita degli Studi di Parma, Italy \\ 2 al-Farabi Kazakh National University, Almaty, Kazakhstan \\ e-mail: francasco@mail.ru
}

\title{
DIGITALIZATION OF KAZAKHSTAN'S ECONOMY
}

\begin{abstract}
The article is devoted to the problems of adapting the company's strategic management tools to the rapidly changing external environment caused by the intensive development of the digital economy. This article discusses the main trends in the digital business environment at the macro and micro levels, issues of improving the efficiency of using the company's internal potential, and features of competition based on the active use of information and communication technologies.

In today's global environment, digitalization plays a key role, and in some cases a defining role, in the industrial development of countries. In a number of countries, the government has focused on the development of logistics as the main factor for stimulating industrial development.

Digitalization has an impact on all sectors and will lead to changes in the structure of the economy of Kazakhstan as a whole by diversifying and unlocking the potential of non-commodity industries, stimulating startup activity and opening "new industries". The degree of influence of digital technologies in different sectors is heterogeneous, the largest value creation potential is expected in the framework of traditional branches of economy, including the commodity sector, but also opens new opportunities of value creation in e-Commerce, the it sector and the financial industry.
\end{abstract}

Keywords: digital economy, information market, information and communication technologies (ICT).

Introduction. It is impossible to imagine the modern world without information technologies that have changed and facilitated various areas and opened up new market opportunities. The emergence of new digital infrastructures, the development of computer technologies and digital communications create new opportunities in the field of information technologies, their implementation in the socio-political and economic life of society, and form a new system of the international economy - digital.

The digital economy is based on the production of electronic goods and services by high-tech business structures and the sale of these goods through e-Commerce (Baumol, 1962)

The digital economy is an activity in which the key factors of production are data presented in digital form, and their processing and use in large volumes, allows you to increase the efficiency, quality and productivity of labor in various types of production, technologies, equipment, storage, sale, delivery and consumption of goods and services.

The subject of the digital economy is economic relations and laws. Relations are formed in the process of production, exchange, distribution and consumption of scientific and technical information through digital information technologies, and the development of these processes is subject to economic laws.

The relevance of the article is due to technological changes that bring new characteristics both to the world economic system and to the economy of individual markets and enterprises. Digital technologies have led to a revolution in business. The new digital economy is based on 
fundamentally different rules than the traditional economy. Business entities are forced to work in constantly changing conditions. Survival and development in such conditions requires constant adaptation of the business to the dynamically changing environment at the strategic and tactical levels.

The purpose of the article is to identify the impact of digital information technologies on business and suggest ways to respond to the challenges of the digital economy.

Literature review: As Steve jobs said: "Let's think of something better than worrying about what happened yesterday."

As Professor W. Brenner of the University of St. Gallen (Switzerland) put it: "aggressive use of data transforms business models, promotes new products and services, creates new processes, generates greater utility, and introduces a new management culture" (What is digital economy, 2017).

Former President of Kazakhstan Nursultan Nazarbayev: - We need to explain to people in General what it is eaten with, what digitalization is. Digitalization is not a panacea. This is only part of the industrial revolution 4.0, which is a very big task. Explain that this is a great thing."

Valentin Katasonov, economist, Professor at MGIMO-University: - It is alarming that the idea of a digital economy is being imposed from the outside. There is a feeling that all this will not end well. In my opinion, first of all it is necessary to take care of the country's information security.

The economic effect of the introduction of industrial technologies of the Internet of things by 2025 may amount to about \$1.2-3.7 trillion in the world. (McKinsey, 2015).

According to a senior Chinese official, Li Ying, the use of Internet technologies " transforms the structure... industry and contributes to its development " (Zhang, 2018, p. 31).

From the point of view of the Eastern school, China, according to Professor Gao Xuanyang, will be able to overcome emerging threats by using new readings of the best examples of traditional culture and their introduction into the minds of people (Gao, 2013).

"On my instructions, a separate Department for digitalization is being created in the akimat. Its tasks are to ensure the implementation of new Smart city projects, complete the automation of public services, and create conditions for the annual rapid growth of the it sector in Almaty, " Bakytzhan Sagintayev said.

Managing Director for digitalization and transformation of the national welfare Fund "Samruk-Kazyna" Dauren kereybayev:

- For many, the concept of "digitalization" is still a mystery. Let me give you an example: our national nuclear company Kazatomprom has launched a digital mine. What does it mean? This is a software and hardware complex that allows you to collect and analyze information from sensors of devices and equipment in real time, remotely control and regulate the number of chemical reagents used in uranium mining. It minimizes the human factor and provides operational control over production. The system allows you to analyze the implementation of production plans, identify deviations in a timely manner, and helps determine the causes of deviations.

- Grandiose transformations of Kazakhstan's economy have begun. It will not be an exaggeration if I call this event historic for us, " said D. Abayev.

Primary partition. The digital economy has a huge impact on production, trade, transport and financial services, education, health, mass media, etc. Technology expands the capabilities of people and organizations in various fields, makes it possible to create and distribute ideas, develop and implement innovations in commercial activities.

The development of the information digital economy is inextricably linked to the development of the information market. The information market can be described as a system of economic, legal and organizational relations for the purchase and sale of intellectual labor products on a commercial basis.

With the growth of Informatization and digitalization of society, the information industry begins to dominate the economy, and production becomes more innovative and knowledgeintensive. The number of people employed in the field of information and communication 
technologies is growing every year. The main factor that has stimulated the Informatization of society in recent decades is the increase in the availability of hardware and software, as well as the development of network technologies. The dynamic development of the information market was significantly influenced by the intensive growth of the software development business (Albanse J, 2016).

The development of the digital economy has led to a new type of competition hypercompetition. The system elements of hypercompetition are multilevel and multi-aspect, new knowledge (competencies), manageability, dynamism, adaptability, mobility, innovation, efficiency, etc., which determine the globalization advantages of the world's leading countries and technologically advanced multinational companies.

In the information market, special methods of competition are used by it structures that perform a narrowly focused function of developing innovative technologies for production, storage, processing and transmission of information to optimize business processes of organizations (Bennet Stewart 1994).

At the microeconomic level, information and communication technologies (ICTs) allow enterprises to optimize their business processes. At the macroeconomic level, the impact of ICT explains the need to choose new directions for the development of the economies of States and regions that take into account the trends in the development of the world economy, including its use.

The digital economy allows you to overcome a number of limitations inherent in the traditional economy. Digital products can be copied and used by an unlimited number of people, but they do not lose their consumer properties, and when they are shared, these properties often improve. At the same time, material products cannot be used by several people at the same time and are subject to wear and tear during operation. Online stores allow you to avoid restrictions on the areas that are typical for conventional trading platforms, and therefore on the breadth of the range.

Material and Methods. With the growing influence of information on company management, more research is needed on how it is used. At present, it is becoming more and more difficult to solve organizational and managerial tasks of companies by organizing business processes. The digital economy has made a number of significant changes in the activities of companies:

The emergence of an information production factor that has become a significant resource.

Increasing production costs, since information as a product and factor has a price.

Reducing transaction costs through the use of ICT. Increasing the importance of the human factor in the implementation of production based on ICT. Reducing the significance of the uncertainty factor due to the active use of the information resource.

In the traditional economy, the main role in the relationship between the manufacturer and the buyer was played by the manufacturer himself, since it was he who owned the generation of the product idea. The buyer made a choice from the list of products already produced and offered by the manufacturer. In the digital economy, the modern consumer has the opportunity to become a participant in the process of creating a new consumer value, generating ideas for new products and services.

The move towards closer interaction with the consumer can be described as a logical step by manufacturing companies to change the business environment. Production companies are increasingly cooperating with the consumer (creating product design, manufacturing a product on an individual order, developing the functionality of a new product, etc.). (Afnach, 2003).

The concept of "open innovation", developed By G. Chesborough, is also associated with changes caused by the digital economy. Open innovations can be observed in the process of actively attracting consumers by business to participate in the process of creating innovations, when companies use not only internal ideas (ideas of employees), but also external ones (ideas of consumers). In the digital economy, knowledge is a strategically important asset. They play a key role in the sustainable economic development of companies in various industries. In this regard, it is 
advisable to form new approaches to developing business development strategies based on modern tools and methods for integrating corporate knowledge into the company's management system. Knowledge management, as one of the most important activities in the management system, should be focused on the formation of intellectual values, the development of organizational, consumer and human capital of enterprises. Intensive use of intellectual assets provides opportunities for the formation of internal and external competencies, which together form a system of key competencies of the company.

Over the past decades, the world has been rapidly moving towards a new type of economy, where digital technologies are becoming the main tool for its formation. Expanding the role of information technology in the work of the private and public sectors is the basis for the transition to a digital state.

According to the forecasts of leading world experts, by 2020, $25 \%$ of the world economy will be digital, and the introduction of digitalization technologies that allow the state, business and society to interact effectively is becoming an increasingly large-scale and dynamic process.

The government and state bodies of Kazakhstan, realizing the importance of Informatization of society and the development of digital technologies in determining long-term economic growth, take an active part in the development of this sphere as one of the key areas of state policy.

Digital transformation is one of the main goals of the modern state. Kazakhstan also pays much attention to this area.

The state program "Information Kazakhstan-2020", approved in 2013, became the Foundation for the digital transformation of the economy of Kazakhstan. She contributed to the development of the transition to the information society, improvement of state management, establish institutions of "open and mobile government", increasing the availability of information infrastructure not only for corporate bodies but also for citizens. According to the results of three years of implementation of the state Program, it has already been achieved by $40 \%$. However, the rapid development of information technologies on a global scale dictates its own rules and in Kazakhstan in 2017, the state program "Digital Kazakhstan" was adopted, which aims to accelerate the pace of development of the country's economy, as well as improve the quality of life of the population through the use of digital technologies.

Results and Discussion. The main goal of the new state program is the progressive development of the digital ecosystem to achieve sustainable economic growth, increase the competitiveness of the economy and the nation, and improve the quality of life of the population. This programmer is conducted in four key areas: implementation of the digital silk road (is the development of reliable, affordable, high-speed and secure digital infrastructure), the development of creative companies (it is the development of competencies and skills for the digital economy, works to increase digital literacy, training of ICT specialists for the industries), the digital transformation in sectors of the economy (this is widespread introduction of digital technologies to enhance the competitiveness of various sectors of the economy), transition to a proactive state (this is an improvement of the system of electronic and mobile government, optimization of the scope of public services).

The program consists of five key areas:

- "Digitalization of economic sectors»;

- "Transition to a digital state»;

- "Implementation of the digital silk road»;

- «Human capital development»;

- "Creating an innovative ecosystem".

Within these five areas, 17 initiatives and more than 100 events have been formed. The country's economy is increasingly being digitized. In 2018, the percentage of organizations using computers increased from $70.7 \%$ to $77.7 \%$. Meanwhile, the share of organizations with Internet access increased from $67.7 \%$ in 2017 to $75.1 \%$ in 2018, and the share of organizations with Internet resources increased from $21.7 \%$ to $22.3 \%$.According to the press service of the Ministry of digital 
development, defense and aerospace industry, the total economic effect of digitalization in Kazakhstan amounted to $\$ 578$ million. USA. The official information resource of the Prime Minister of Kazakhstan reported that due to the introduction of digitalization of the economy, annual productivity growth is expected by $2-10 \%$, production growth at fields - by $3 \%$, reduction of production costs-by $10-20 \%$, increase in productivity due to the use of precision agriculture in agriculture - by $25-50 \%$.

In 2018, the first year of implementation of the Digital Kazakhstan program, investments in the field of information and communications showed a significant increase: $+40.3 \%$ for the year, to 92.5 billion tenge. However, in the first nine months of this year, investments amounted to 46 billion tenge $-10.2 \%$ lower than in the same period last year (51.3 billion tenge). The main areas of investment in fixed assets in the third quarter of 2019: replacement of old equipment (15\%); expansion of production capacity to increase the number of subscribers $(11 \%)$; investment in the introduction of new technologies $(5 \%)$.

The Digital Evolution Index 2017 rating reflects the progress in the development of the digital economy in different countries, as well as the level of integration of the global network into the lives of billions of people.

According to their research, Singapore, the United Kingdom, New Zealand, the United Arab Emirates, Estonia, Hong Kong, Japan and Israel have become the "digital elite": these countries are characterized by a high level and rapid pace of digital development. This speed of innovation in these progressive markets can serve as an example of successful technological progress and a guide for future growth.

Norway, Sweden, Switzerland, Denmark, Finland, Singapore, South Korea, the United Kingdom, Hong Kong, and the United States are among the TOP 10 countries with the most developed digital economy.

After analyzing the current state and growth rates of the digital economy in each state, the authors of the study divided the countries into 4 groups:

Leaders: Singapore, the United Kingdom, New Zealand, the United Arab Emirates, Estonia, Hong Kong, Japan, and Israel demonstrate high rates of digital development, maintain it, and continue to lead the way in spreading innovation.

Slowing growth rates: South Korea, Australia, as well as countries in Western Europe and Scandinavia have been showing steady growth for a long time, but have now noticeably slowed down. Without innovation, these States risk falling behind the leaders of digitalization.

Promising: Despite the relatively low overall level of digitalization, these States are at the peak of digital development and demonstrate steady growth rates, which attracts investors. China, Kenya, Russia, India, Malaysia, the Philippines, Indonesia, Brazil, Colombia, Chile, and Mexico have the potential to take leading positions.

Problematic: countries such as South Africa, Peru, Egypt, Greece, and Pakistan face serious challenges related to low digital development and slow growth.

In the key global ranking of ICT development calculated under the UN aegis - the ICT Development Index - Kazakhstan was ranked 52nd out of 175 in 2016, having not changed its position since 2015. As a result of the implementation of the Program and other strategic directions, the country will rise in the ranking to 30 th place by 2022 , 25th place by 2025 and to 15 th place by 2050 .

Kazakhstan is also a catch-up country in the e-intensity rating of the international consulting company the Boston Consulting Group in terms of the current level of digitalization. To overcome the catch-up status in the Program, it is necessary to have revolutionary, breakthrough events in all areas of digitalization that are on the agenda of the world's countries.

These areas include digital transformation of traditional sectors of the economy, development of human capital, digitalization of government agencies, development of digital infrastructure, as well as a breakthrough in the development of the business ecosystem in the field of digital 
technologies and, as a result, changing production models and creating added value in the real sector of the economy.

However, Kazakhstan does not start from scratch. In the 90s, the state program for accelerated industrial and innovative development was launched, the Bolashak international education program was initiated, and the formation of an "electronic government"was started in 2005. Also, a number of elements of the innovation ecosystem have already been created in Kazakhstan, the SEZ "PIT "Alatau", the AEO "Nazarbayev University" is functioning, and the international Technopark Astana hub is being launched. 3/4 of the adult population of our country has a basic level of digital literacy, more than $3 / 4$ have access to the Internet. This is a significant base from which we can start implementing the Program.

In his Message, the President of the country noted that the development of the digital industry will provide an impetus to all other industries and instructed the Government to keep this issue under special control. In this regard, the Head of state set the task of developing new industries that are created using digital technologies.

Thus, the share of the information technology sector in the gross domestic product of South Korea is $9 \%$, in Japan-5.5\%, in China and India-4.7\%, and in Uzbekistan-only 2.2\%. According to the results of the report of the International telecommunication Union, Kazakhstan ranks 52nd among 176 countries in the information and communication development index 2017. However, in the CIS region, Kazakhstan is among the top three, placing in 3rd place after Belarus (32nd place) and Russia (45th place).

The effects of digitalization. According to preliminary estimates, the direct effect of digitalization of the economy by 2025 will create an additional value of 1.7-2.2 trillion. tenge, thus ensuring a return on investment of $4.8-6.4$ times by 2025 to the total volume of investments, taking into account private investment.

Digitalization has an impact on all sectors and will lead to changes in the structure of the economy of Kazakhstan as a whole by diversifying and unlocking the potential of non-commodity industries, stimulating startup activity and opening "new industries". The degree of influence of digital technologies in different sectors is heterogeneous, the largest value creation potential is expected in the framework of traditional branches of economy, including the commodity sector, but also opens new opportunities of value creation in e-Commerce, the it sector and the financial industry.

Successful implementation of the impact of digitalization on the growth of enterprise output by 2022 will mean the following achievements:

- increase the level of labor productivity to the level of the TOP 30 countries in each of the priority industries,

- competitive export production in priority sectors,

- bringing the capitalization of the largest companies to a fundamentally new level,

- developed local e-Commerce.

Reducing the share of the shadow economy to a level comparable to the TOP 30 countries in the world.

The widespread introduction of digital technologies will give impetus to the development of traditional basic industries by ensuring productivity growth and increasing their competitiveness, including in the international market. Thus, as a result of digitalization, the growth of domestic exports to foreign markets will be ensured both in the raw materials industries and in the agroindustrial complex, which, in turn, will lead to an increase in the capitalization of the largest production companies. Also, to increase productivity, the Program provides for the implementation of a set of measures for technological re-equipment of basic industries, where elements of Industry 4.0 will be used.

Kazakhstan, implementing a comprehensive approach to digitalization, nevertheless focused on such basic elements as digitalization of the mining industry and agriculture, further development 
of digital public services and ICT infrastructure. Special attention is paid to the development of human capital and the creation of an innovative ecosystem.

In other words, we are talking about the five main directions Of the state program "Digital Kazakhstan", and the result will depend on the joint efforts of the state and business, as well as the involvement of every citizen of our country.

Digitalization is significantly ahead of the existing system of production requirements for the composition of professions engaged in the labor market.

In order to train professional personnel for industries with a set of digital skills "by default", the subject "Information and communication technologies"has already been introduced in all specialties.

For the development of technical and professional, higher and postgraduate education in order to bring industry and education closer together, measures are envisaged to create ICT departments of higher education Institutions at enterprises, as well as competence centers.

Events are also planned to update educational programs based on professional standards and labor market requirements for new popular professions, such as Data Science, Robotics, Genomics, Nanoelectronics and Nanomechanics, highly qualified developers for developing products using technologies: Artificial Intelligence, Iot solutions, Blockchain, Additive technologies, BIM, etc.

Conclusion. The development of the digital economy has a significant impact on the internal and external business environment. Radical changes are taking place in the field of information and communication technologies, which are reflected in various areas of companies ' activities.

The Internet makes it possible for even new and tiny companies to sell their products all over the world.

Companies can emerge and grow quickly, with relatively small capital investments.

Information technology helps to reduce costs and significantly increase efficiency and productivity in almost all sectors of the economy.

The position of companies on the market in the digital economy is becoming more complex, with increasing risks and uncertainty in making strategic decisions. This situation is associated with unstable market conditions due to dynamic changes at the technological level, increasing competition, and the influence of the state on the economy.

Technological changes inherent in the digital economy create new market rules for doing business, both for producers and buyers. In the digital economic environment, companies need to continuously search for new competitive strategies and improve the effectiveness of competition.

In order to survive and develop in the new environment, companies should increase their competence in the field of digital information technologies.

\section{References:}

Adner R. (2006), Match your innovation strategy to your innovation ecosystem // Harvard Business Review, vol. 84, no. 4, pp. 98-107

Adner R., Kapoor R. (2010), Value creation in innovation ecosystems: how the structure of technological interdependence affects firm performance in new technology generations // Strategic Management Journal, vol. 31, no. 3, pp. 306-333

Afuah A. (2003), Business Models: A Strategic Management Approach. McGrawHill,

Albanese J. (2016), Revive: how to transform traditional businesses into digital leaders. Old Tappan, New Jersey: Pearson Education Inc., 186 p. 298

Allee V. (2015), The future of knowledge: Increasing

Baumol W. (1962), On the Theory of the Expansion of the Firm // American Economic Review, № 52

Bennett Stewart (1994), G. EVA: Fact and Fantasy // Journal of Applied Corporate Finance, no. 2 
Berglöf E., von Thadden L. (1999). The changing corporate governance paradigm: Implications for transition and developing countries. Working Paper, Stockholm Institute of Transition Economics, Review,

Blair M.M., Stout L. (2013), A team production theory of corporate law // Virginia Law

Rudenko G. (2014), Cifrovye tehnologii: novye vozmozhnosti dlja biznesa//JEffektivnoe antikrizisnoe upravlenie №1 (82)-6 s.

Strategija razvitija informacionnogo obshhestva v Rossijskoj Federacii na 2017 - 2030 gody (proekt) $-20 \mathrm{~s}$.

Toffler JE. (2008), Metamorfozy vlasti: znanie, bogatstvo I sila na poroge XXI veka - M.: Izdatel'stvo «AST»,- $669 \mathrm{~s}$.

Chezboro G. (2007) Otkrytye innovacii. Sozdanie pribyl'nyh tehnologij - M.: Pokolenie,$336 \mathrm{~s}$.

Jelektronnaja (cifrovaja) jekonomika. Prilozhenie k Srednesrochnoj programme social'nojekonomicheskogo razvitija Rossii do 2025 g. «Strategija rosta»

Jelkom (2017), Obshhie voprosy jelektronnoj kommercii [Jelektronnyj resurs] Rezhim dostupa: http://elcomrevue.ru/tsifrovaya-ekonomika/

Gartner (2017). Organizacii dolzhny perehodit' na cifrovuju jekonomiku, chtoby realizovat' ves' potencial cifrovogo biznesa [Jelektronnyj resurs] Rezhim dostupa: https://www.crn.ru/news/detail.php?ID=1146407

What is digital economy? (2018). Unicorns, transformation and the internet of things. https://www2.deloitte.com/mt/en/pages/technology/articles/mt-what-is-digital-economy.html

\author{
Ли Моли, ${ }^{1}$ Ш. Абдикул, ${ }^{2}$ С.К. Ахметкалиева ${ }^{3}$ \\ ${ }^{1}$ Universita degli Studi di Parma, Италия \\ 2 әл-Фараби атындағы КазҰУ, Алматы, Казахстан \\ e-mail: francasco@mail.ru
}

\title{
КАЗАКСТАН ЭКОНОМИКАСЫН ЦИФРОВИЗАЦИЯЛАУ
}

Андатпа. Мақала компанияны стратегиялық басқару құралдарының сандық экономиканың қарқынды дамуынан туындаған тез өзгеретін сыртқы ортаға бейімделу мәселелеріне арналған. Бұл мақалада макро - және микродеңгейдегі бизнестің сандық ортасын өзгертудің негізгі тенденциялары, компанияның ішкі әлеуетін пайдалану тиімділігін арттыру мәселелері, ақпараттық-коммуникациялық технологияларды белсенді пайдалануға негізделген бәсекелестік күрес ерекшеліктері қарастырылған.

Қазіргі жаһандық жағдайларда цифрландыру негізгі, ал кейбір жағдайларда елдердің индустриялық дамуында шешуші рөл атқарады. Бірқатар елдерде үкімет логистиканы индустриялық дамуды ынталандырудың негізгі факторы ретінде дамытуға баса назар аударды.

Цифрландыру барлық секторларға әсер етеді және шикізат емес салалардың әлеуетін әртараптандыру және ашу, стартап-белсенділікті ынталандыру және "жаңа салаларды"ашу жолымен тұтастай алғанда Қазақстан экономикасының құрылымын өзгертуге алып келеді. Бұл ретте түрлі салаларда цифрлық технологиялардың ықпал ету дәрежесі бірдей емесқұнды құрудың ең үлкен әлеуеті Қазақстан экономикасының дәстүрлі салалары, оның ішінде шикізат секторы шеңберінде болжанып отыр, сондай-ақ электрондық саудада, АТсекторында және қаржы индустриясында құнды құрудың принципті жаңа мүмкіндіктері ашылады.

Түйінді сөздер: сандық экономика, ақпараттық нарық, ақпараттық-коммуникациялық технологиялар (АКТ). 


\author{
Ли Моли, ${ }^{1}$ Ш. Абдикул, ${ }^{2}$ С. Ахметкалиева ${ }^{3}$ \\ ${ }^{1}$ Universita degli Studi di Parma, Италия \\ ${ }^{2}$ КазНУ имени аль-Фараби, Алматы, Казахстан \\ e-mail: francasco@mail.ru
}

\title{
ЦИФРОВИЗАЦИЯ ЭКОНОМИКИ КАЗАХСТАНА
}

Аннотация. Статья посвящена проблемам адаптации инструментов стратегического управления компанией к быстро меняющемуся внешнему окружению, вызванным интенсивным развитием цифровой экономики. В данной статье рассмотрены основные тенденции изменения цифровой среды бизнеса на макро- и микроуровне, вопросы повышения эффективности использования внутреннего потенциала компании, особенности конкурентной борьбы, основанной на активном использовании информационнокоммуникационных технологий.

В современных глобальных условиях цифровизация играет ключевую, а в некоторых случаях определяющую роль в индустриальном развитии стран. В ряде стран правительство сделало ставку именно на развитие логистики как основного фактора стимулирования индустриального развития.

Цифровизация имеет влияние на все сектора и приведет к изменению структуры экономики Казахстана в целом путем диверсификации и раскрытия потенциала не сырьевых отраслей, стимулирования стартап-активности и открытия «новых отраслей». При этом степень влияния цифровых технологий в разных отраслях неоднородна - наибольший потенциал создания стоимости предполагается в рамках традиционных отраслей экономики Казахстана, в том числе сырьевого сектора, но также открываются принципиально новые возможности создания стоимости в электронной торговле, ИТ-секторе и финансовой индустрии.

Ключевые слова: цифровая экономика, информационный рынок, информационнокоммуникационные технологии (ИКТ). 